\title{
The Effect of Quantum Learning Model on Science Teacher Candidates' Self-Efficacy and Communication Skills
}

\author{
Özlem Afacan ${ }^{1}$, İpek Gürel ${ }^{2}$ \\ ${ }^{1}$ Faculty of Education, Kırşehir Ahi Evran University, Kırşehir, Turkey \\ ${ }^{2}$ Science and Technology Teacher, Fatih Secondary School, Manisa, Turkey \\ Correspondence: Özlem Afacan, Faculty of Education, Kırşehir Ahi Evran University, Kırşehir, Turkey.
}

Received: February 11, 2019

Accepted: March 6, 2019 Online Published: March 13, 2019

doi:10.11114/jets.v7i4.4026

URL: https://doi.org/10.11114/jets.v7i4.4026

\begin{abstract}
The aim of this study was to investigate the effect of quantum learning model on science teacher candidates' self-efficacy and communication skills. One group pre-test post-test experimental design was performed in the study. The research was carried out with 20 teacher candidates having education in third grade of Division of Science Education in Ahi Evran University. A total of 16 hours' seminar was given to the teacher candidates in the research group about "Quantum Learning Model" and the techniques used in quantum learning model. The application of the research was performed in 8 weeks and in a total of 32 hours with laboratory experiments arranged in accordance with the "Quantum Learning Model" in the course of Science Teaching Laboratory Practices-II. Before and after the experimental studies, "Science Teaching Self-Efficacy Belief Questionnaire" and "Self-Awareness Inventory" were performed on teacher candidates. The obtained data were analyzed by SPSS package program. According to the results of the research, there was no significant difference between the science teacher candidates' science teaching self-efficacy pre-test and post-test mean scores. Between the mean scores of science teacher candidates in science teaching self-efficacy pre-test and post-test, there was a significant difference in favor of post-test.
\end{abstract}

Keywords: quantum learning model, self-awareness, self-efficacy

\section{Introduction}

\subsection{Introduce the Problem}

In today's information and communication age, countries are constantly changing and developing in cultural, social, economic and technological fields. Adapting to these necessities of the time can only be achieved by means of well-educated individuals (Brooks \& Brooks, 1993). Science is defined as the process of thinking about the nature of knowledge, discovering the present knowledge and producing new knowledge (Çepni, Ayas, Johnson \& Turgut, 1997).

In Science Teaching Curriculum of 2018, all individuals were aimed to become a scientific literate (MEB, 2018). Scientific literacy is to know the concepts and theories of science, and to explain the events encountered in the daily life with science, to understand the changeability of scientific knowledge and to know the concepts of science, technology and society and the relationship between these concepts (Afacan, 2008). Scientific literacy includes the nature of science, scientific initiatives, and the role of science in social and personal life. Students need to understand what is science or not, what it can do or cannot do, and how the science integrates with culture. Science literacy is to know and understand the scientific concepts and methods necessary to participate in economic productivity, cultural and civil events and make personal decisions (NSES, 1996).

Science teachers should tell their students science is everywhere! By this means, the students should be able to use their knowledge effectively in their daily life and also be able to really understand the concepts of learning to learn and lifelong learning.

One of the recommended learning theories in science education is the quantum learning model for students to be able to reach scientific knowledge, to encode the information with their own processes and to use them for a long time.

\subsection{Quantum Learning Model}

The concept of quantum is mostly used in physics. The quantum theory explains the invisible atomic world (Taslaman, 
2008). For the events that Newton physics cannot solve, quantum theory is able to produce solutions in micro and macro environment (Ay, 2010). Quantum learning model was developed on the basis of the explanation of quantum as "the interaction that transforms energy into light" by Bobbi De-Porter in the United States in 1980s (DePorter \& Hernacki, 1992). According to Vella (2002), quantum learning is the use of all the neural networks of the brain to create information. Quantum learning takes place within a brain-based learning approach (DePorter \& Hernacki, 1992). According to Walsh (2002), suggestopedia is how the human brain works and how it works effectively (p.18).

Quantum learning can be expressed as a learning theory that allows combining all the neural structures in the brain in a personal way in order to create meaningful information. This model aims to provide students with academic and lifelong learning skills.

While academic skills are note-taking, memory, writing and effective reading techniques, lifelong learning skills are problem solving techniques, effective communication skills and eight keys of perfection (be totalitarian, errors lead to success, positiveness, focus on target, try to perform the ideals, attach importance to every work, be open to new approaches and thoughts and balance) (Demir, 2006). In the quantum teaching model, a supportive and reassuring teaching environment where everyone is valued and respected (DePorter, Reardon \& Singer-Nourie, 1999).

Quantum learning is one of the models in which research is effective and that have many other important factors such as effective applications, funny learning environment, leadership, communication skills and gaining higher mental skills (Usta, 2006). Quantum teaching is the learning process realized by providing backgrounds and strategies to improve the learning-teaching process and make this process more fun. In this manner, a teaching style is upskilled that gives students the power to achieve as much success as possible, and it also allows teachers to develop their skills (Suryani, 2013). At this stage, in each student' self-actualization process, on the part of the students, to learn how to learn, in other words to know the art of learning is of vital importance (Demirel, 2012).

In quantum learning theory, the student is able to discover the information with his own processes and can use the memory methods used in the long-term memory of the brain. Thus, he can easily access the information he wants at any time.

The concept of self-efficacy was first included in the social learning theory developed by Bandura in 1986. According to Bandura; self-efficacy is that the individual can use his capacity effectively (Bandura, 1993). Likewise, self-efficacy is defined as the belief in the capacity of individuals to organize and realize the activities and actions necessary to perform a certain performance (Bandura, 1997). As individuals' self-efficacy beliefs increase, they imagine their future more positively (Bandura, Barbaranelli, Caprara \& Pastorelli, 2001).

Communication is a vital skill we use in every moment of life. According to Demir (2006), another important issue on which quantum learning focuses is communication skills. People want to have socially acceptable behaviors that enable communication and interaction with others, and these skills are generally referred to as social skills (Yüksel, 2004). In other words; communication skills are under the roof of social skills. According to Yüksel (2004), social skills are taking social knowledge in interpersonal relations; appropriate responses are learnable behaviors that include both observable and unobservable cognitive and affective elements that vary according to the target and social context. The process of communicating with others is an advantage in education. In this respect, quantum learning also focuses on communication skills. Communication training, which has become indispensable nowadays, provides students with the skills to gain an advantage in the process of accessing information. In order for the teachers to establish healthy relationships with their students and to give them new behaviors, they must first communicate with their students in a correct manner (Afacan \& Turan 2012). Individuals with effective communication skills are more willing to learn and have higher self-efficacy (Hanbay, 2009; Nourie, 1998).

When the studies on the competencies of the teacher in our country are examined; it is seen that this knowledge is approached, for many years, in three groups as "content knowledge", "teaching knowledge" and "general culture knowledge" (Afacan, Özbek \& Aydoğdu, 2017). A teacher needs to know the subjects in his/her field, the relationships between these issues and other fields and the necessity to teach this field, i.e. the objectives of the field. A mathematician is expected to know the maths likewise; a historian is expected to know the history. However, in the matter of separating the information on which teaching is based, the main point that distinguishes a field teacher from a field expert is the ability to enable interaction of field knowledge and educational knowledge, in other words, it is the ability of the teacher to adapt the field knowledge in an educationally effective way according to the diversity of the students' backgrounds and their abilities (Shulman, 1987). Teaching is a profession that requires many fields of knowledge to coexist. Therefore, it is necessary to investigate the technology, pedagogy and field information of teacher candidates who will become future teachers, and the links between this information should also be investigated (Afacan \& Cemil, 2017; Kartal \& Afacan, 2017).

When the literature is examined, it is seen that there are researches about the achievements (Ar1 \& Alaca, 2015; Barlas, 2002; Benn, 2003; Demir, 2006; Hanbay, 2009; LeTellier \& Depoter, 2002; Kusno \& Purwanto, 2011; Muga, 2017; 
Nourie, 1998; Suwarni, Tarjana, Slamet \& Ngadiso, 2014; Trice, 2012; Vos-Groenendal, 1991; Zeybek, 2018) and attitudes (Ay, 2010; Nourie, 1998; Vos-Groenendal, 1991) of the students and the opinions of the teacher candidates and teachers (Karamustafaoglu \& Karamustafaoglu, 2018; Sarıgöz, Cengiz \& Koca, 2015) in teaching environments organized according to quantum teaching model. It was seen that there wasn't any study investigating the effect of quantum learning model on science teacher candidates' self-efficacy and communication skills. For this reason, it is thought that the research which will make a quantum learning model on the teacher candidates who will constitute the future teachers, prepare the students for life, produce the right solutions for the problems, and make the students easily apply what they learn in daily life.

\subsection{Aim}

The aim of this study was to investigate the effect of quantum learning model on science teacher candidates' self-efficacy and communication skills. For this purpose, the following hypotheses were established for this purpose:

$\mathrm{H}_{1}$. Application of quantum learning model; science teacher candidates have a significant diversity on science teaching self-efficacy.

$\mathrm{H}_{2}$. Science teacher candidates' Science Teaching Self-Efficacy Belief Questionnaire post-test mean scores differ according to gender and place of residence variables.

$\mathrm{H}_{3}$. Application of quantum learning model; science teacher candidates have a significant diversity on science communication skills of science teacher candidates.

$\mathrm{H}_{4}$. Science teacher candidates' Self-Awareness Inventory post-test mean scores differ according to gender and place of residence variables.

\section{Methodology}

\subsection{Research Model}

The research design was based on a one group pre-test and post-test model that aims to perform both pre-experiment and post-experiment measurements by applying an independent variable to a selected group (Karasar, 2005).

\subsection{Research Group}

The research was carried out with 20 teacher candidates in the third grade of department of science education in Ahi Evran University. Demographic characteristics of the teacher candidates in the study group according to "gender" and "place of residence" were given in the table 1.

Table 1. Demographic characteristics of the research group

\begin{tabular}{lll}
\hline Characteristics & f & $\%$ \\
\hline Gender & & \\
\hline Female & 13 & 65.00 \\
Male & 7 & 35.00 \\
\hline Place of Residence & 11 & 55.00 \\
\hline Metropolitan & 5 & 25.00 \\
Province & 2 & 10.00 \\
District & 2 & 10.00 \\
Village & & \\
\hline
\end{tabular}

According to table 1, 13 female and 7 male teacher candidates participated in the study. The teacher candidates stated their place of residence as follows, 11 of them in metropolitan, 5 in province, 2 in district and 2 in village.

\subsection{Data Collection Tools}

\subsubsection{Science Teaching Self-Efficacy Belief Questionnaire}

"Science Teaching Self-Efficacy Belief Questionnaire" was developed by Yaman (2003). This developed test was examined by experts and concluded that the test is valid. For this 30-item scale, Yaman (2003) found Cronbach alpha $(\alpha)$ reliability coefficient as to be 0.84 . For the positive items of the scale, "strongly agree" and "agree" statements were used, for the negative items; "strongly disagree" and "disagree" statements were used.

\subsubsection{Self-Awareness Inventory}

In order to measure the communication skills of science teacher candidates, "Self-Awareness Inventory" was used, which was developed by Riggio (1986) and Turkish adapted by Yüksel (1997). According to Yüksel (1997), social skills inventory includes six subscales that measure social communication skills at two levels as affective and social levels. The reliability coefficient for the scores obtained from the whole scale was given as 0.94 , in addition, the reliability coefficients obtained from the subscales ranged from 0.81 to 0.96 . 
The social skills inventory consists of a total of 90 items and consists of six subscales. The respondents of the inventory make markings on the answer sheet, by using the 5-point Likert scale, after deciding on the degree to which they meet the definitions in each item (Yüksel, 1997).

Although it is an inventory of social skills, the name of the inventory is referred to as "Self-Awareness Inventory". The reason for this is to prevent the respondents from being too excited and sensitive due to thinking of social skills as socially acceptable during the response process (Yüksel, 2004). In the research, the inventory was answered by teacher candidates in laboratory conditions, in a quiet and calm environment and without time constraints.

\subsection{Data Collection}

The subjects covered in the scope of the Science Teaching Laboratory Practices-II course in the research were designed with Quantum Learning Techniques. The course of Science Teaching Laboratory Practices-II includes experiments using simple and cheap materials related to physics, chemistry and biology. In order to be able to apply the course in accordance with quantum teaching, a teaching plan was prepared by the researcher before the lesson. Seminars were given to the research group about the technique to be applied every week in order to be able to process the courses in accordance with quantum techniques.

The implementation process started with a seminar. The seminars in total took 24 hours. Experiments were applied with quantum learning techniques in 8 hours. In the seminars, the aim and techniques of quantum were demonstrated in practice. Necessary precautions had been taken to prevent teacher candidates from experiencing problems about the techniques. The teacher candidates were asked to develop experiments in group in accordance with the lesson plan and the subject, then, the experimental processes were reported by means of note TM (note-taking and note-making method). At the beginning of the course, the quotes of the famous thinkers and philosophers were written on the blackboard, during the course the classical music was played, and the motivation of the teacher candidates was provided by various pictures and stimulant texts in the classroom. Teacher candidates were asked to keep a diary at the end of each course. The diaries were weekly evaluated and the deficiencies were eliminated as occasion requires. During the process, some quantum techniques such as note TM, mind mapping and mind nails techniques were used.

\subsection{Data Analysis and Statistical Techniques}

In the data analysis, it was examined whether the average scores of the science teaching self-efficacy scores and the self-knowledge inventory average scores showed normal distribution before using statistical techniques. For this reason, Kolmogorov-Smirnov test was performed. Kolmogorov-Smirnov value was found to be as $p>.05$ which was normally scores. While data were analyzed normally t-test was used for parametric tests, t-test for unrelated samples, and one-way analysis of variance (ANOVA) (Can, 2014).

\section{Results and Comments}

\subsection{Results and Comments Related to Self-Efficacy Levels of Science Teacher Candidates}

In order to determine whether the application of quantum learning model given to the science teacher candidates has a significant effect on science teaching self-efficacies of them, paired samples t-test was conducted. The t-test results of "the Science Teaching Self-Efficacy Belief Questionnaire" mean scores of science teacher candidates for related measurements are given in Table 2.

Table 2. Independent Samples t-test of science teacher candidates regarding the Science Teaching Self-Efficacy Belief Questionnaire pre-test and post-test mean scores

\begin{tabular}{ccccccc}
\hline Measurement & N & M & $\begin{array}{c}\text { Std. } \\
\text { Deviation }\end{array}$ & df & t & Sig \\
\hline Pre-test & 20 & 104.92 & 10.60 & 19 & 0.62 & 0.54 \\
\hline Post-test & 20 & 107.12 & 16.07 & & & \\
\hline
\end{tabular}

When Table 2 is examined, no significant difference was found between the pre-test mean scores and post-test mean scores of science teaching self-efficacy scale of science teacher candidates $\left(t_{(19)}=0.62, p>.05\right)$. However, it is seen that the science teaching self-efficacy post-test means $(M=107.12)$ of science teacher candidates were higher than their pre-test mean scores $(\mathrm{M}=104.92)$.

3.2 Results and Comments Related to "Gender" Variable of Science Teacher Candidates' Post-test Mean Scores in "Science Teaching Self-Efficacy Belief Questionnaire"

In order to determine whether the post-test mean scores of Science Teacher Candidates in "Science Teaching Self-Efficacy Belief Questionnaire" differed according to the "gender" variable, t-Test was performed for Independent Samples and the results are given in Table 3. 
Table 3. Independent samples t-Test related to "Gender" variable of "Science Teaching Self-Efficacy Belief Questionnaire" post-test mean scores of science teacher candidates

\begin{tabular}{lllclcc}
\hline Gender & $\mathbf{N}$ & $\mathbf{M}$ & $\begin{array}{c}\text { Std. } \\
\text { Deviation }\end{array}$ & df & t & Sig. \\
\hline Female & 13 & 108.58 & 9.24 & 18 & 0.541 & 0.595 \\
\hline Male & 7 & 104.42 & 25.18 & & & \\
\hline
\end{tabular}

In Table 3, when the post-test mean scores of "Science Teaching Self-Efficacy Belief Questionnaire" according to the genders of science teacher candidates, it is seen that self-efficacy post-test scores of female students $(\mathrm{M}=108.58)$ were higher than the self-efficacy post-test scores $(\mathrm{M}=104.42)$ of male students. However, this difference between the scores of teacher candidates in "Science Teaching Self-Efficacy Belief Questionnaire" is not statistically significant $\left(\mathrm{t}_{(18)}=\right.$ $0.541, \mathrm{p}>.05)$.

3.3 Results and Comments Related to "Place of Residence" Variable for Science Teacher Candidates' Post-test Mean Scores in "Science Teaching Self-Efficacy Belief Questionnaire"

In order to determine whether the post-test mean scores of Science Teacher Candidates in "Science Teaching Self-Efficacy Belief Questionnaire" differed according to the "place of residence" variable, one-way analysis of variance (ANOVA) was performed for Independent Samples and the results are given in Table 4.

Table 4. One-Way analysis of variance (ANOVA) results related to "place of residence" variable for "Science Teaching Self-Efficacy Belief Questionnaire" post-test mean scores of science teacher candidates

\begin{tabular}{lccccc}
\hline Source of Variance & $\begin{array}{c}\text { Sum of } \\
\text { Squares }\end{array}$ & df & Mean Square & F & Sig. \\
\cline { 1 - 4 } Between Grups & 58.974 & 3 & 19.658 & 0.065 & 0.978 \\
\cline { 1 - 4 } Within Grups & 4850.054 & 16 & 303.128 & & \\
\hline Total & 4909.028 & 19 & & \\
\hline
\end{tabular}

When the results in Table 4 are examined, in the one-way analysis of variance (ANOVA) between the groups and within the groups, it is seen that there was no statistically significant difference between the post-test mean scores of teacher candidates in "Science Teaching Self-Efficacy Belief Questionnaire" according to the "Place of Residence" variable (F $(3-16)=0.065, \mathrm{p}>.05)$.

\subsection{Results Related to Communication Skills Levels of Science Teacher Candidates}

In order to determine whether the application of quantum learning model given to the science teacher candidates has a significant effect on communication skills of teacher candidates paired samples t-test was conducted for related samples. The t-test results of "Self-Awareness Inventory" mean scores of science teacher candidates for related measurements are given in Table 5.

Table 5. Independent Samples t-Test for the related measurements of Self-Awareness Inventory pre-test and post-test mean scores of science teacher candidates

\begin{tabular}{lllcccc}
\hline Measurement & N & M & $\begin{array}{c}\text { Std. } \\
\text { Deviation }\end{array}$ & df & t & Sig. \\
\hline Pre-test & 20 & 273.28 & 27.16 & 19 & 3.06 & 0.00 \\
\hline Post-test & 20 & 286.49 & 26.21 & & & \\
\hline
\end{tabular}

When Table 5 is examined, a significant difference was found between the pre-test mean scores and post-test mean scores of science teacher candidates in "Self-Awareness Inventory" $\left(\mathrm{t}_{(19)}=3.06, \mathrm{p}<.05\right)$. However, it is seen that self-test inventory post-test means ( $M=286.49)$ of teacher candidates are higher than their pre-test mean scores $(M=273.28)$.

3.5 Results and Comments Related to "Gender" Variable for Science Teacher Candidates' Post-Test Mean Scores in "Self-Awareness Inventory"

In order to determine whether the post-test mean scores of science teacher candidates in "Self-Awareness Inventory" differed according to the "gender" variable, t-test was performed for Independent Samples and the results are given in Table 6.

Table 6. Independent Samples t-Test related to "Gender" variable of "Self-Awareness Inventory" post-test mean scores of science teacher candidates

\begin{tabular}{|c|c|c|c|c|c|c|}
\hline Gender & $\mathbf{N}$ & $\mathbf{M}$ & $\begin{array}{c}\text { Std. } \\
\text { Deviation }\end{array}$ & df & $\mathbf{t}$ & Sig. \\
\hline Female & 13 & 286.35 & 30.43 & 18 & 0.032 & 0.173 \\
\hline Male & 7 & 286.75 & 17.97 & & & \\
\hline
\end{tabular}

When Table 6 is examined, for the post-test mean scores of science teacher candidates in "Self-Awareness Inventory" according to the gender, it is seen that self-awareness inventory mean scores of male students $(M=286.75)$ were higher 
than the mean scores of female students $(M=286.35)$. However, this difference between teacher candidates' Self-Awareness Inventory mean scores was not statistically significant $\left(\mathrm{t}_{(18)}=0.032, \mathrm{p}>.05\right)$.

3.6 Results and Comments Related to "Place of Residence" Variable for Science Teacher Candidates'Post-Test Mean Scores in "Self-Awareness Inventory"

In order to determine whether the post-test mean scores of science teacher candidates in "Self-Awareness Inventory" differed according to the "place of residence" variable, one-way analysis of variance (ANOVA) was performed for independent samples and the results are given in Table 7.

Table 7. One-Way Analysis of Variance (ANOVA) results related to post-test mean scores of science teacher candidates in "Place of Residence" variable of "Self-Awareness Inventory"

\begin{tabular}{lccccc}
\hline Source of Variance & $\begin{array}{c}\text { Sum of } \\
\text { Squares }\end{array}$ & df & Mean Square & F & Sig. \\
\hline Between Grups & 4077.999 & 3 & 1359.333 \\
\cline { 1 - 4 } Within Grups & 8977.737 & 16 & 2.423 & 0.104 \\
\hline Total & 13055.736 & 19 & & & \\
\hline
\end{tabular}

When the results in Table 7 are examined, for one-way analysis of variance between the groups and within the groups, it is seen that there is no statistically significant difference between the post-test mean scores of teacher candidates in "Self-Awareness Inventory" according to the "place of residence" variable $\left(F_{(3-16)}=2,423, p>.05\right)$.

\section{Discussion and Conclusion}

This study was carried out to investigate the effect of quantum learning model on science teacher candidates' self-efficacy and communication skills. One group pre-test post-test experimental design was performed in the study. The research was carried out with 20 teacher candidates having education in the third-grade department of science education in Ahi Evran University. A total of 16 hours' seminar was given to the teacher candidates in the research group about "Quantum Learning Model" and the techniques used in quantum learning model. As data collection tools, "Science Teaching Self-Efficacy Belief Questionnaire" and "Self-Awareness Inventory" were performed on teacher candidates.

According to the results of the research, there was no significant difference between the science teacher candidates' science teaching self-efficacy pre-test and post-test mean scores. The fact that the research process is not long enough to change the self-efficacy characteristics of the teacher candidates can be considered as the reason of lack of a significant change in the pre-test and post-test scores.

As a reason why, the quantum learning model does not differ in the level of affecting the self-efficacy mean scores of science teacher candidates, it is thought that this is due to the fact that self-efficacy is resistant to change and that it can change in a long time (Tschannen-Moran \& Hoy, 2001). When the post-test mean scores of science teacher candidates in "Science Teaching Self-Efficacy Belief Questionnaire" according to gender variable, although the self-efficacy post-test scores of the female students were higher than the self-efficacy post-test scores of male students, it was found that this difference was not statistically significant in terms of gender variable. Hackett, Betz, Casas \& Rocha-Singh (1992) and Chu (2003) stated that self-efficacy did not change according to gender variable. Unlike the research results, Bleicher (2004) examined the science teacher candidates according to the gender variable and found a significant difference in favor of male teacher candidates. In the literature, in some studies, self-efficacy was found to be significantly different in favor of female students (Ablard \& Lipschultz, 1998; Joo, Bong \& Choi, 2000; Kalaian \& Freeman, 1994; Pokay \& Blumenfeld, 1990; Zimmerman \& MartinezPons, 1990).

There was no significant difference between the pre-test and post-test mean scores of teacher candidates in "Science Teaching Self-Efficacy Belief Questionnaire" according to the "place of residence" variable.

A significant difference was found between the pre-test and post-test mean scores of science teacher candidates in "Self-Awareness Inventory". This result shows that quantum learning increases the communication skills of science teacher candidates. The fact that the teacher candidates should have an effective communication skill is supported by the conducted studies (Acar, 2009; Afacan \& Turan, 2012).

However, it is seen that the self-awareness inventory post-test means of the teacher candidates are higher than their pre-test mean scores. Based on this, it can be said that teacher candidates are able to improve their communication skills, which are indicative of self-awareness, by using the communication skills in the life skills department of the quantum learning model. It was seen that the "Self-Awareness Inventory" post-test mean scores of Science Teacher Candidates did not make a significant difference according to the "gender" variable. It is similar to the results of studies indicating that communication skills do not show a significant difference according to gender variable (Acar, 2009; Pehlivan Baykara, 2005; Tümkaya, 2011; Ulukan, 2012). 
In the post-test mean scores, male teacher candidates were found to be higher than the mean score of female teacher candidates. The reason for this is that the number of male teacher candidates in the research group is less than the number of female teacher candidates. The results did not show a significant change between the gender post-test scores. Also, in the study conducted by Cetinkaya (2011), female students' communication skills scores were higher than the male students'. Similar results can be seen in the studies conducted by Çuhadar, Özgür, Akgün \& Gündüz (2014) and Yılmaz \& Altunbaş (2012). However, Dalkılı̧ (2011) and Elkatmış (2015) concluded that the communication skill levels of the students, which are indicative of self-awareness, did not show a significant change according to their gender.

Self-Awareness Inventory pre-test and post-test results showed that there is no significant difference in communication skills according to the "place of residence" variable of teacher candidates. Acar (2009) stated that there is no significant difference between teacher candidates' communication skills according to the place where their family live.

The quantum learning model makes a significant contribution to the teacher candidates' ability to increase their academic achievement by using more of their brain activities, to discover their own learning techniques and to make their information permanent. However, it is also important to teach quantum learning model to teacher candidates in terms of using effective teaching techniques for their students and teaching the acquired knowledge.

It is also stated that quantum learning model can be used to change the behaviors of children with behavior disorders (Wajdi, 2017).

\section{Recommendation}

The recommendations given according to the research findings are given below.

1. In the education process of the teacher candidates studying at the faculties of education, in order to develop effective communication skills, elective courses can be planned.

2. Quantitative learning applications can be applied to the curriculum of the faculties of education as an elective course.

3. True experimental design studies can be performed on teacher candidates studying in different departments by means of quantum learning model.

4. The effect of quantum learning on the different skills of teacher candidates, such as academic achievement, attitude, cognitive skills, creative thinking skills and scientific process skills can be examined.

5. Activities based on the quantum learning model for science course can be organized for teacher candidates.

\section{Acknowledgments}

This study was produced from a part of master thesis prepared by İpek GÜREL in Kırşehir Ahi Evran University, Graduate School of Natural and Applied Science, Department of Science Educationunder the supervisor of Associate Professor Özlem AFACAN.

\section{References}

Ablard, K. E., \& Lipschultz, R. E. (1998). Self-regulated learning in high-achieving students: Relations to advanced reasoning, achievement goals, and gender. Journal of Educational Psychology, 90(1), 94-101. https://doi.org/10.1037/0022-0663.90.1.94

Acar, V. (2009). Communication skills of teacher candidates [Öğretmen adaylarının iletişim becerileri in Turkish], Unpublished master dissertation. Mehmet Akif Ersoy University Social Sciences Institute, Burdur.

Afacan, Ö. (2008). Elementary school students' perception levels of relationship between science-technology-society-environment (STSE) and determination of scientific attitude (sample of Kirşehir city) [İlköğretim öğrencilerinin fen-teknoloji-toplum-çevre (FTTÇ) ilişkini algllama düzeyleri ve bilimsel tutumlarının tespiti (Kırşehir ili örneği) in Turkish], Unpublished doctoral dissertation. Gazi University Institute of Educational Sciences, Ankara.

Afacan, Ö., \& Turan, F. (2012). Using creative drama method for determining pre-service science teachers' perceptions of the communication skills. Erciyes University Journal of Social Sciences Institute, 33(2), 211-237. Retrieved from http://erciyes.dergipark.gov.tr/erusosbilder/issue/23767/253365

Afacan, Ö., Özbek, N., \& Aydoğdu, M. (2017). Senior pre-service science teachers' views about science teaching. Researcher: Social Science Studies, 5 (9), 304-320. https://doi.org/10.18301/rss.305

Afacan, Ş., \& Cemil, M. (2017). Music teacher candidates' technological pedagogical content knowledge. Abant İzzet Baysal University Education Faculty of Journal, 17(3), 1079-1100. Retrieved from

http://efdergi.ibu.edu.tr/index.php/efdergi/article/view/2488/3424 
Ar1, E., \& Alaca, Ö. (2015). The effect of quantum learning models on science lesson achievement, attitude, retention and evaluation. Asian Journal of Instruction, 3(1), 30-49. Retrieved from http://dergipark.gov.tr/download/article-file/17671

Ay, Y. (2010). The effect of science and technology education based on quantum learning model to the academic success, attitude towards lesson and self direct learning on elementary students [Kuantum ögrenme modeline dayall fen ve teknoloji eğitiminin ilkögretim ögrencilerinin akademik başarl, derse yönelik tutum ve kendi kendine öğrenme becerileri ïzerine etkisi in Turkish], Unpublished master dissertation. Osmangazi University Institute of Science and Technology, Eskişehir.

Bandura, A. (1993). Perceived self-efficacy in cognitive development and functioning. Educational Psychologist, 28(2), 117-148. https://doi.org/10.1207/s15326985ep2802_3

Bandura, A. (1997). Self-efficacy: The exercise of control. Newyork: Freeman.

Bandura, A., Barbaranelli, C., Caprara, G. V., \& Pastorelli, C. (2001). Self-efficacy beliefs as shapers of children's aspirations and career trajectories. Child Development, 72(1), 187-206. Retrieved from https://doi.org/10.1111/1467-8624.00273

Barlas, L. (2002). Quantum learning effects on student attitudes toward learning and academic achievement, Unpublished master dissertation. Aurora University, Chicago.

Benn, W. (2003). Evaluation study of quantum learning's impact on achievement in multiple settings, Unpublished master dissertation. Department of Education, California University, California.

Bleicher, R. E. (2004). Revisiting the STEBI-B: Measuring self-efficacy in preservice elementary teachers. School Science \& Mathematics, 104(8), 383-391. https://doi.org/10.1111/j.1949-8594.2004.tb18004.x

Brooks, J. G., Brooks, M. G. (1993). In search of understanding: The case for constructivist classrooms. Alexandria, VA: Association for Supervision and Curriculum Development.

Can, A. (2014). Quantitative data analysis in scientific research process with SPSS[SPSS ile bilimsel araşttrma sürecinde nicel veri analizi in Turkish] Second press. Ankara: Pegem A Academy.

Çepni, S., Ayas, A., Johnson, D., \& Turgut, F. (1997). Physics teaching, YÖK / World Bank National Education Development Project; Initial teacher training, [Fizik Öğretimi. YÖK/Dünya Bankası Milli Eğitimi Geliştirme Projesi; Hizmet Öncesi Öğretmen Eğitimi in Turkish], Ankara. Retrieved from http://hskizilcik.com/fizik/egitim/FizikOgretimi.pdf

Çetinkaya, İ. (2011). The relationship between leadership styles and communication skills of school administrators in secondary education [Ortaögretim okul müdürlerinin liderlik stilleri ve iletişim becerileri arasindaki ilişki in Turkish], Unpublished master dissertation. Gazi University Institute of Educational Sciences, Ankara.

Chu, L. (2003). The effect of web page design instruction on computer self-efficacy of preservice teachers and correlates. Journal of Educational Computing Research, 28(2), 127-142.https://doi.org/10.2190/K79G-2PYY-VVU6-X988.

Çuhadar, C., Özgür, H., Akgün, F., \& Gündüz, Ş. (2014). Teacher candidates' communication skills and communicator styles [Öğretmen adaylarının iletişim becerileri ve iletişimci biçimleri in Turkish] Ahi Evran University Kırşehir Journal of Faculty of Education, 15(1), 295-311. Retrieved from http://dergipark.gov.tr/download/article-file/15822

Dalkılıç, M. (2011). Elementary school students partıcıpation in sports actıvitıes and communication skalls level ınvestigatıon of relatıonships between [İlköğretim ögrencilerinin sportif faaliyetlere katılım düzeyi ve iletişim becerileri arasındaki ilişkilerin incelenmesi in Turkish](Unpublished master dissertation). Karamanoğlu Mehmetbey University Social Sciences Institute, Karaman.

Demir, S. (2006). The effect of Quantum learning model on the students' success at secondary education (an experimental study in Gaziantep) [Kuantum öğrenme modelinin ortaöğretim düzeyinde ögrenci başarısina etkisi (Gaziantep örneği) in Turkish], Unpublished doctoral dissertation. Gaziantep University Social Sciences Institute, Gaziantep.

Demirel, Ö. (2012). Curriculum development in education [Eğitimde program geliştirmein Turkish] 19th press. Ankara: Pegem A Publication.

DePorter, B., \& Hernacki, M. (1992). Quantum learning: Unleashing the genius in you. New York: Dell Publishing Group.

DePorter, B., Reardon, M., \& Singer-Nourie, S. (1999). Quantum teaching: Orchestrating student success. Need hamHeights, MA: Allynand Bacon.

Elkatmış, M. (2015). The effect of effective communication courses with written and spoken expression on communication skills of pre-service teachers. Elementary Education Online, 14(4), 1341-1351. https://doi.org/10.1705/io.2015.58970 
Hackett, G., Betz, N. E., Casas, J. M., \& Rocha-Singh, I. A. (1992). Gender, ethnicity, and social cognitive factors predicting the academic achievement of students in engineering. Journal of Counseling Psychology, 39, 527-538. https://doi.org/10.1037/0022-0167.39.4.527

Hanbay, O. (2009). Die wirkung der methode "lernen durch lehren" auf der basis von "quantum-lernen" auf das lernen vom deutschen als tartiärspache. Dicle University Ziya Gökalp Journal of Faculty of Education, 1(12), 17-27. Retrieved from http://zgefdergi.com/Makaleler/516557122_12_02_Hanbay.pdf

Joo, Y. J., Bong M., \& Choi, H. J. (2000). Self-efficacy for self-regulated learning, academic self-efficacy, and internet self-efficacy in web-based instruction. Educational Technology Research and Development, 48(2), 5-17. https://doi.org/10.1007/BF02313398

Kalaian, H. A., \& Freeman, D.J. (1994). Gender differences in self-confidence and educational beliefs among secondary teacher candidates. Teaching and Teacher Education, 10(6), 647-658. https://doi.org/10.1016/0742-051X(94)90032-9

Karamustafaoğlu, O., \& Karamustafaoğlu, S. (2018). Teacher's views about "How does light propagation?" activity developed based on quantum learning model. Journal of The International Scientific Researches, 3(2), 528-536. https://doi.org/10.21733/ibad.429258

Karasar, N. (2005). Scientific research method.[Bilimsel araştırma yöntemi in Turkish], $15^{\text {th }}$ press. Ankara: Nobel Publication.

Kartal, T., \& Afacan, Ö. (2017). Examining Turkish pre-service science teachers' technological pedagogical content knowledge (TPACK) based on demographic variables. Journal of Turkish Science Education, 14(1), 1-22. https://doi.org/10.12973/tused.10187a

Kusno, M., \& Purwanto, J. (2011). Effectiveness of quantum learning for teaching linear program at the muhammadiyah senior high school of Purwokertoin Central Java, Indonesia. EDUCARE: International Journal for Educational Studies, 4(1), 83-92.

LeTellier, P. J., \& DePorter, B. (2002). Quantum learning for teacher. Oceanside: Learning Forum Publication, California.

MEB (2018). Curriculum of science courses (Primary, Secondary, 3rd, 4th, 5th, 6th, 7th and 8th Grades), Ministry of National Education Board of Education, [Fen bilimleri dersi öğretim programı (İlkokul ve Ortaokul 3, 4, 5, 6, 7 ve 8. Sınıflar), MEB Talim ve Terbiye Kurulu Başkanlığı,] Ankara. Retrieved from http://mufredat.meb.gov.tr/ProgramDetay.aspx?PID=325.

Muga, W. (2017). Video assisted quantum learning design to improve psycomotoric learning achievement. Journal of Education Technology, 1(1), 30-36. Retrieved from https://ejournal.undiksha.ac.id/index.php/JET/article/viewFile/10081/6417

Nourie, S. S. (1998). Results of implementing quantum learning in the Thornton Township High School district. Unpublished master dissertation, Saint Xavier University, Chicago.

NSES (NATIONAL SCIENCE EDUCATION STANDARDS) (1996). National Research Council, Washington DC: National Academy Press.

Pehlivan, B. K. (2005). A study on perception of communication skills of preservice teachers. Elementary Education Online, 4(2), 17-23. Retrieved from http://dergipark.gov.tr/download/article-file/91073

Pokay, P., \& Blumenfeld, P.C. (1990). Predicting achievement early and late in the semester: The role of motivation and use of learning strategies. Journal of Educational Psychology, 82, 41-50. https://doi.org/10.1037/0022-0663.82.1.41

Riggio, R. E. (1986). The assessment of basic social skills. Journal of Personality and Social Phychology, 51(3), 649-660. https://doi.org/10.1037/0022-3514.51.3.649

Sarıöz, O., Cengiz, M. Ş., \& Koca, M. (2015). The evaluation of attitudes and views of preservice teachers on quantum-based learning. International Peer-Reviewed Journal of Humanities and Academic Science. April / May / June Spring Summer, 4 (12), 114-128. http://10.17368/UHBAB.2016128914

Shulman, L. S. (1987). Knowledge and teaching: Foundations of the new reform. Harvard Educational Review, 57(1), 1-23. https://doi.org/10.17763/haer.57.1.j463w79r56455411

Suryani, N. (2013). Improvement of students' history learning competence through quantum learning model at senior high school in Karanganyar Regency, Solo, Central Java Province, Indonesia.Journal of Education and Practice,4(14), 55-63. Retrieved fromhttps://www.iiste.org/Journals/index.php/JEP/article/download/6798/6912

Suwarni, S, Tarjana, S. S., Slamet, Y., \& Ngadiso. (2014). English teaching material development as an alternative source in teaching English at junior high schools. International Journal of Research Studies in Language Learning, Special 
Issue, 3(6), 95-105.https://doi.org/10.5861/ijrsll.2014.722

Taslaman, C. (2008). Quantum theory, philosophy and God [Kuantum teorisi, felsefe ve Tanrt in Turkish]. İstanbul: İstanbul Publishing.

Trice, T. Y. (2012). Quantum Learning: Making prodigiousstrides in education. Unpublished doctoral dissertation, Trevecca Nazarene University, Nashville, TN.

Tschannen-Moran, M., \& Hoy, A. W. (2001). Teacher efficacy: capturing an elusive construct. Teaching and Teacher Education, 17(7), 783-805. https://doi.org/10.1016/S0742-051X(01)00036-1

Tümkaya, S. (2011). İnvestigation of communication skills and attitude to teaching of the students of primary school teaching. Çukurova University Journal of Social Sciences Institute, 20(2), 49-62. Retrieved from http://dergipark.gov.tr/download/article-file/50678

Ulukan, H. (2012). The effect of communication skills on team and individual athletes [İletişim becerilerinin takum ve bireysel sporculara olan etkisi in Turkish],Unpublished master dissertation. Karamanoğlu Mehmetbey University Social Sciences Institute, Karaman.

Usta, E. (2006). Quantum learning: Teachers and students. Primary Education Educator Journal, December, 4, 20-25.

Vella, J. (2002). Quantum learning: teaching as dialogue. New Directions for Adult and Continuing Education, Spring, No. 93. pp. 73-83. https://doi.org/10.1002/ace.51

Vos-Groenendal, J. (1991). Research of participants' perceptions after attending supercamp. Unpublished doctoral dissertation. Northern Arizona University, Flagstaff Arizona.

Wajdi, M. B. N. (2017). Optimization of game character education based on traditional physical education of children with behaviour and emotional problems through learning model quantum learning. International Journal of Psychology, 1(1), 25-32.

Walsh, D. (2002). An analysis of the competencies that instructors need to teach using accelerated learning. Unpublished master thesis, The Graduate College University of Wisconsin Stout, Wisconsin.

Yaman, S. (2003). The effects on the learning outputs of problem-based learning in science education [Fen Bilgisi eğitiminde probleme dayalı ögrrenmenin ögrenme ürünlerine etkisi in Turkish], Unpublished doctoral dissertation. Gazi University Institute of Educational Sciences, Ankara.

Yılmaz, N., \& Altunbaş, S. (2012). Investigation of preservice teachers communication and classroom management skills. Erzincan University Journal of Faculty of Education, 14(1), 183-196. Retrieved from https://www.pegem.net/dosyalar/dokuman/138282-2013122510316-11.pdf

Yüksel, G. (1997). The effect of social skills training on social skills of university students [Sosyal beceri eğitiminin üniversite ögrencilerinin sosyal beceri düzeyine etkisi in Turkish], Unpublished doctoral dissertation. Gazi University Institute of Educational Sciences, Ankara.

Yüksel, G. (2004). Inventory of social skills [Sosyal beceri envanteri in Turkish] Ankara: Asil Publication

Zeybek, G. (2018). The effect of the activities based on quantum learning model on academic achievement. International Journal of Education Sciences and Learning Technology, 1(1), 22-31. Retrieved from http://dergipark.gov.tr/download/article-file/471362

Zimmerman, B. J., \& Martinez-Pons, M. (1990). Student differences in self-regulated learning: Relating grade, sex, and giftedness to self-efficacy and strategy use. Journal of Educational Psychology, 82(1), 51-59.

https://doi.org/10.1037/0022-0663.82.1.51

\section{Copyrights}

Copyright for this article is retained by the author(s), with first publication rights granted to the journal.

This is an open-access article distributed under the terms and conditions of the Creative Commons Attribution license which permits unrestricted use, distribution, and reproduction in any medium, provided the original work is properly cited. 